\title{
The Role of Religious Authorities in Constructing Peace: The Case of Albania
}

\author{
PhD. Cand. Adil Kutlu \\ Department of Islamic Sciences, Faculty of Humanities \\ Hëna e Plotë-Beder University, Tirana, Albania \\ akutlu@beder.edu.al
}

DOI:10.5901/mjss.2014.v5n19p500

\begin{abstract}
Today's communities have a more heterogeneous structure ever before. It is an observable fact that people, who have different religions, languages and ethnic origins, live in the same society. In such societies which have differences, the peace and tranquility is provided by mutual understanding, dialogue and tolerance. For this reason, the governments, politicians and religious institutions need to take more responsibilities. The aim of this study is to put forth, by means of the Albanian case, that religious institutions and organizations in general and religious officials in particular have the influence on raising consciousness and guiding people not only about religious subjects but also about social issues. Within this context, in 1997, in northern Albania, Shkoder city, it has been analyzed how H. Faik Hoxha the Mufti of Shkoder, Lucjan Avgustini the Parson of Catholic Church of Shkoder and Aleksander Petani the Archpriest of Orthodox Church of Shkoder played an effective role as religious officials in preventing the provocation which was fictionalized by taking advantage of political authority gap. In this study, qualitative research methodology has been used and aforementioned Shkoder incident has been analyzed as the case study. Along with the articles authored by those who witnessed the incident being in the first place, the other books and articles have been examined by scanning method and the findings have been evaluated. The study concludes that religious officials also play an important role in a state of chaos and anarchy probable in societies giving its place to indulgence and reconciliation and also they are effective upon restoration of peace by contributing to creating an atmosphere of dialogue and tolerance.
\end{abstract}

Keywords : Religious Authorities, Constructing Peace, Indulgence, Tolerance, Dialogue

\section{Introduction}

As a social being, human, has to live in communities to continue his life. If we have a look at ancient times we will see that human being has lived in communities from that time. We shouldn't consider these communities as a simple thing.

"As an organism has a structure also each society has a structure. With social structure we understand, organised social relations in society and result of their interactions from the straightforward integrity"(Türkkahraman, 2009, p. 27).

From the perspective of institutions sociology, we generally can note five governmental institutions. They are indispensable elements of society, such as family, education, economics, politics and religion. Referred to as the five key institutions they can be found in all communities. (Yaka, 2011,).

This study will emphasize the importance of religion that is considered one of the major institutions of society, in the eyes of people, and will present with concrete examples the positive impact of clergy on the people.

\section{1 - Religion as a Social Institution}

Every society has a number of its own fundamental dynamics. When this dynamics begin to deteriorate it's possible to see dissolution of social structure. One of the most important social dynamics is religion. (Turan, 2007, p. 294)

Religion is a requirement of human nature and it is an important need for individual and social life. In order to meet this requirement, whether or not it is a source of divine, in every era has believed in one religion. (Klavuz\&Yılmaz, 2009, p. 125). 
Religion with the principles of faith and worship that it contains is a phenomenon that always has a big impact on culture. The role of religion is largely in the formation of common values, culture, in formation and development of morality in people live together. (Kutlu\&Kutlu, 2013, p. 28).

Religion continues to be prominent now days in domestic realm of individual and social life as in every period of history. Besides recognizing oneself and contributing to the development of one's personality religion is observed to be capable in treating positively people who wear the face of in different social events. Besides creating social assurance and peace religion has been the basis of many social events such as happiness, solidarity and justice. (Oruç, 2008, p. 134)

Reaching even the areas beyond where law can't reach, awareness people inviting them to positive behaviors and conscience religion is an active element.

Some of the moral values that are counted as human qualities such as goodness, truth, compassion, respect and patronage which bonds society and people together are based on religious and moral principles.

\section{2 - Function of Clergy in Society}

An important role and impact within legal people in social life and individuals has the Clergy. Clergy is fulfilling an important mission in teaching religion and conveys messages to society.

On the one hand preaching, sermons and liturgy in worshiping places clergy inform the religious aspects to coreligionists, on the other hand calling people to solidarity, respect and cooperation, and provide an invaluable contribution in social peace by warning people to avoid behaviors that damage unity and cooperation. Ensuring the peace in the society people meet at the common denominator of leaving in the same community even if they are of different races, beliefs and mindset. Communities that come together around certain ideals and form a solid structure they have the opportunity to preserve their culture, faith , briefly they continue to preserve their identity in peace. (YIImaz, 2001, p. 333)

Clergy that are serving in religious institutions, besides of educating people morally they are in a position to guide them in many issues.Clergy that gets along well with everyone in society he is currently, exhibits a compatible personality, have good dialogues with people, listen to their problems, show love and compassion to poor and shabby by visiting them, make peace between litigious and resentful, this kind of clergy will be the symbol of peace. (Yılmaz, 2001, p. 341).Instead of this Clergy shouldn't feed hatred and cuts against people because of their political opinions and religious preferences but should tolerate and compromise differences in the name of social peace.

\section{3- The Religious Structure in Albania}

The first advent of new monotheistic religion Christianity in Albania was in the end of 2nd century AD by the Greeks from the Bishops that has been sent. This new religion found a favorable environment in the territory of Albania which was dominated by the ancient Roman culture. However the Slavic invasion that took place between 7 th and 9th century bottom up the Greek tradition in this region and people returned to the ancient cultural tradition. (Bozbora, 1997, p. 35-36)

Christianity started to be efficient in Albania again in 9th century with the invasion of the Byzantine, from this time up to the present Southern Albania continued to become Orthodox. In the 12th century the Roman Catholic Church started a war against Greek Orthodox Church which led to rule of Catholic Church in north, so Albanian population was divided into a religious. (Bozbora, 1997, p. 36)

Albanians first contacted with Islam and the traces of Islamization were found to be in the early stages.Pre-medieval Albanian territory was a haunt of the Arab and Turkish missionaries with different purpose over the Islamic world before Ottoman Empire. However, the process of Islamization of the Albanian population began and developed in the 15th century with the arrival in the region of the Ottoman Empire. When it came to XVI century Islam became most effective religion in the regions which inhabited by Albanians (Kutlu\&Kutlu, 2013, p. 27).

When Albania gained the independence in 1912, according to statistics made in 1938 and $194269 \%$ of the population is Muslim, 21\% Orthodox Christian, while 10\% is designated as Catholic Christian. (Özkan, 2012, p. 295)

Between the years 1945-1985 Albania was ruled by Enver Hoxha for forty years by Marxist-Leninist ideology and Stalinist dictatorship ignoring the concept of religion in 1967 proclaimed the country "atheist" and banned all religions. Not satisfied with this, Enver Hoxha added atheism belief in Albania's Constitution in 1976 and so deprived the belief liberty of people. 
When Enver Hoxha died in 1985, Ramiz Alia became the new leader. In Alias time the rules of religion matters had been loosened, and then religious freedom was brought to people.

After the collapse of the communist regime in 1990, the activities of religious organizations opened all mosques, churches and other religious institutions. (Özkan, 2012, p. 310).

In contrast to the statistics in 1938 and 1942,at the present, according to the Albanian Institute of Statistics (INSTAT) carried out by the 1 to 21 October 2011 the religion distribution in the country: 56.70\% Muslim, Bektashi 2.09\%, 10.03\% Catholic, Orthodox $6.75 \%, 0.14 \%$ Evangelist $0.07 \%$ Other Christians, saying that they are believer $5.49 \%, 2.50 \%$ Atheist $0.02 \%$ Other, $13.79 \%$. \%, 2.43\% are described as invalid-worthless (INSTAT, 2011, p. 71).

There is a good example regarding to the mutual understanding, dialogue and tolerance. For example, in 1997, there was a bankruptcy crisis in Albania. With the promise of high interest the bankers took a large amount of money from the people in the beginning , but they didn't fulfill their promise. Some of them escaped abroad with the money they took and some of them declared bankruptcy. The people, who gave money, blamed the government for the bankruptcy, and they started to protest the government in every corner of the country. Due to the protest, some police and people died in the Volora city. People started to arm themselves due to the disorder (Bytyçi, 1997).Despite the strict rules from the government, in early march the government lost its control of Vlore, Saranda, Gjirokastra and Tepelena. The rebels were advancing toward the capital Tirana and something very bad happened in Elbasan city which is located in center of Albania. News began to spread that pro-government south people armed against north people. The developments were in favor of the possibility of a confrontation of Tosks in north and Gegs in south (Bytyçi, 1997).As a consequence, some people tried to start chaos in Shkoder city, which is the northern city of Albania Genti Kruja (2008), who was a witness of the incident that had happened, explains: Till the march 13 the city was in silence and then a group of citizens spoke among themselves of possible chaos, looting and stealing, they gathered in front of the Hall building and requested weapons from the government. Local authorities remained silent on the demands of the people, but some citizens attacked a military arms deported and those that were experienced in other cities, included the city of Shkoder .

There were rumors that Serbian-Montenegrin army was approaching, people of Shkoder built stone barricades and hard materials to defend the city against a possible attack. That night they gave a fake alarm that poisonous substance was thrown into the water and to inform people the speakers of "Fushe Celes" and "Pjace" mosques were used. The important event happened on 14th march on Friday, although there were security risks most people came from rural areas to pray the "Friday prayer" in the largest mosque in the city Centre transmits Kruja. Despite the barricades in the streets the Muslims filled the mosque.

The reason for this extraordinary mobility was unclear by whom it was written, and the news spread with lightning speed, and after it was understood that it was a written letter.

In the letter was written that the Mosque would be blown up by the Catholics. And at the same day, another letter was sent to the Catholic Church which was built in 1857, that Muslims would blow up the Church.

Looking how cosmopolitan and how the city was structured we can clearly see the severity and the size of provocation. Living for years in peace and consisting the majority from Muslims and Catholics, they wanted to start chaos among the people that were living in Shkoder.

The representative of the Church, the priest Lucjan, wonted to learn the truth about the event and he came to the Mosque during the Friday prayer, and waited there until the worship ended.

After the prayer he met the Mufti of Shkoder, H. Faik Hoca, and then went to the Mufti's office. In the office they talked about how danger would it be if the temples were blown up and then the dialog would break, which would cause a terrible result of incidents and violence, and talked on alternative ideas. One of the ideas proposed was that the Catholic priest would stay the night in the mosque and the Muslims representatives would stay all night at the Church.

So if a member of their own religion or a group of looters came to harm the temple, both of temples would be protected by each other. At the end of the meeting they came to the conclusion that both sides who wanted to perform such actions cannot be members of any religion, so they would not hesitate in killing the priest that was in Mosque or the Muslim Mufti in Church, so both of sides decided to protect their own temples.

So that night both sides protected their own temples against possible attacks. But the news was fake so there didn't happen any attack against Mosque or Church. Only in a small community of orthodox, their small wooden church was burned from unknown reasons, but Priest Aleksander Petani and his community didn't use this case for solicitation. More interestingly 
the mayor of Shkoder in that period Bahri Borici, both with the religious representing Shkoder Mufti H. Faik Hoxha, Shkoder Catholic Church priest Lucjan Avgustini and Shkoder Orthodox Church priest Aleksander Petani, walked along the streets with a speaking trumpet. They urged people to behave prudently and cold-blooded not to fall into the trap of provocation and not to harm the tolerance and interfaith harmony. As it is seen in the picture blow, they were all walking together.

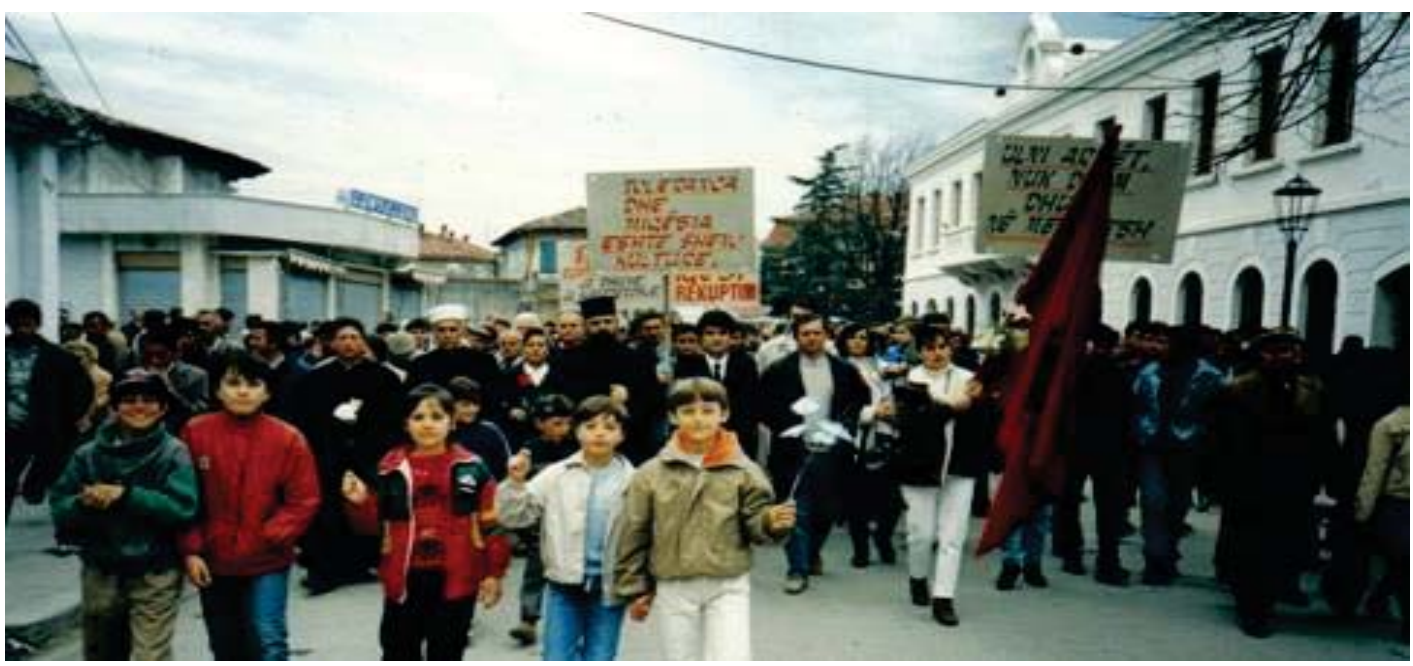

Genti Kruja claims that this phenomenon is rare in its kin not only for Albania but it is an example for the whole world, so when the government becomes weak and can't protect, the local authorities should be effective and ask help from the religious communities in order to protect society to maintain peace and prosperity and lead a normal life in the future (Kruja, 2008).

\section{Conclusion}

In every period of human history people have created communities, but this doesn't seem to be ordinary and meaningless association.Family, education, economy, politics and religion are institutions like in every healthy societies which have become an indispensable element that regulates social life. If the basic dynamics of the society are unable to do their function it is inevitable to have dissolution in society.

Having an enormous impact on culture, mentioned within social institutions, religion is seen to be the guarantee of peace and tranquility. Bringing people closer to each other, holding them together are basic principles based on religious and moral. Reaching the places beyond the law can reach, where there have a lack of authority, acknowledge people, invite them to engage in positive behaviors and conscience are some positive elements that religion provides.

The events which happened in Shkoder show the impact and the significant place that religion and clergy has impact on society. Beside teaching the religion and applying it, clergy have an important contribution in leading people to solidarity, respect and tolerance and warn them to stay away from behaviors that can damage social tranquility and peace.

Having the power to organize people and crowds easily, we can see the name of many clergy in the past in a lot of war organizations. Religion authorities should not use hatred language against anyone, but they have an important role in building peace and tranquility and to protect it

Nowadays interfaith dialogue, tolerance, love and peace supported by clergy, are drawing a different portrait of society. The events that happened in Shkoder in 1997 once again demonstrated the importance of dialogue.

Being calm against possible provocations, investigating and learning the truth can prevent disasters. Investigating the heard news, and even in most difficult time not leaving the dialogue in Shkoder the fruits of all these were peace.

Both clerics come together without hesitation because this outrageous plans might damage the persons that belongs to their religion, supports the idea that there is no place for terrorism in religion. It is a good example of cooperation between 
state authorities and religion communities, that state can ask for help where it cannot ensure the safety and falls in weakness, without interfering and without competing with each other.

\section{References}

Bozbora, N. (1997). Osmanlı Yönetiminde Arnavutluk ve Arnavut Ulusçuluğu'nun Gelişimi. İstanbul: Boyut Matbaacılık.

Bytyçi, E. (1997). Banker Krizinden Kuzey-Güney Savaşına. Aksiyon Dergisi.

http://www.aksiyon.com.tr/aksiyon/haber-2371-banker-krizinden-kuzey-guney-savasina.html (27.05.2014)

Instituti I Statistikes. (2012). Censusi I Popullsisë dhe Banesave 2011. Tiranë: Adel Print.

http://www.instat.gov.al/media/178070/rezultatet_kryesore_t_censusit_t_popullsis_dhe_banesave_2011_n_shqip_ri. pdf (28.05.2014)

Kılavuz, M. A. \& Yılmaz, H. (2009). Örgün ve Yaygın Eğitimde Öğrenenlerin İhtiyaçları Doğrultusunda Din Eğitimi ve Öğretimi. Uludağ

Üniversitesi İlâhiyat Fakültesi Dergisi. Cilt: 18, Sayı: 2, pp. 123-139

Kruja, G. (2008). Në 11 Vjetorin e Një Dite Tolerance të Pashembullt në Shkodër. Drita Islame, Viti XVII, Nr. 3, p. 4.

Kutlu A. \&Kutlu A. (14-16 Kasım 2013). İslam Dini'nin Arnavutçaya Kazandırdığı Kelimeler. 2. Uluslararası Dil ve Edebiyat Konferansı

"Balkanlarda Türkçe" Bildiri Kitabı II. Tirana/Albania: Hëna e Plotë Bedër University, pp. 25-32

Oruç, C. (2008). Din Kişisel ve Sosyal Bir İhtiyaçtır. Fırat Üniversitesi Illahiyat Fakültesi Dergisi. 13:2, pp. 129-141

Özkan, A. (2012). Enver Hoca Döneminde Arnavutluk'ta Din-Devlet İlişkisi. History Studies International Journal of History. Volume 4. Issue 4,

pp. 293-316.

Turan, İ. (2007). Medyadaki Din Adamıİmajı̈̈zerineBazıDüşünceler.Ondokuz Mayıs Üniversitesi İlahiyat Fakültesi Dergisi. Sayl: 24-25, pp.

291-304

Türkkahraman, M. (2009). Teorik ve Fonksiyonal Açıdan Toplumsal Kurumlar ve Kurumlararası Ilişkiler. Süleyman Demirel Üniversitesi İktisadi

ve İdari Bilimler Fakültesi Dergisi. Cilt.14, Sayı: 2, pp. 25-46.

Yaka, A. (2011). Sosyal Kurumlar ve KurumlașmaSüreci,

http://www.aydinyaka.com/index.php/tum-makaleler/28-sosyal-kurumlar-ve-kurumlasma-sureci.html (25.05.2014)

Yılmaz, H. (2001). Yaygın Din EğitimiKurumları veToplumsal Barış. Cumhuriyet Üniversitesi İlahiyat Fakültesi Dergisi.cilt: V, sayı: 2, pp. 329-

356 